\title{
Se
}

\section{Georgian approach to COVID-19}

\section{Zurabi Jankhoteli (student) ${ }^{1}$ and Paul Gibbs (advisor) ${ }^{2}$}

1 East European University Faculty of Business and Engineering, Program of Business Administration (Management), Tbilisi, Georgia

2 Emeritus Professor, Middlesex University, London, UK

* Correspondence: Email: p.gibbs@mdx.ac.uk

Received 27 November, 2020; Revised 2 February, 2021; Accepted 4 February, 2021

Available online 5 February, 2021 at www.atlas-journal.org, doi: 10.22545/2021/00154

\section{Short Letter}

The COVID-19 pandemic, declared a global threat by the World Health Organization 2020, is a new challenge in the modern world. The virus has spread to almost every country, and this fact has affected many aspects, including the economy and healthcare. A new crisis has begun in the world, which is very difficult to overcome. ${ }^{1}$ When the spread of the virus had just begun in the Chinese city of Wuhan, meanwhile Georgian government started discussion about the seriousness of this virus.

In Georgia, the virus had a negative impact on the economy, healthcare and the social status of citizens. To some extent, the crisis triggered by fears of a pandemic, as so far no governing body, as well as the public, has had no experience in dealing with threats of a similar magnitude. The ongoing processes in the world have become force majeure due to the rapid growth of the pandemic, resulting in the inability to share, use and coordinate the knowledge, which countries have accumulated in the fight against the virus. If such in-depth studies were available, Georgia would be able to reduce the expected economic downturn based on their analysis. As soon as the first case of Covid infection was confirmed, citizens panicked and began to over-purchase food and necessities for further storage and use. This fact caused the first micro shock to the economy, which was manifested in the depreciation of the national currency against the dollar, in its instability, in addition there arose to the real threat to logistics and supply. ${ }^{2}$ Rising unemployment, rising risk of bankruptcy for small and medium-sized businesses, rising poverty rates, stagnant tourism businesses and declining international remittances are a combination of aspects that play an important role in shaping Georgia's economic climate. ${ }^{3}$ The deterioration of these indicators means the aggravation of the economic crisis inside the country.

According to the data, the contribution of tourism is $21.3 \%$ of Georgia's GDP, ${ }^{4}$ thus the problems created in this segment will be dramatically reflected on the business entities operating in this sector as well

\footnotetext{
${ }^{1}$ World Health Organization. 19.06.2020. WHO Director-General's opening remarks at the media briefing on COVID-19 www.who.int

${ }^{2}$ National Bank of Georgia. 05.12.2020. Official exchange rate of LARI against foreign currencies 24.02.2020 - 05.03.2020 www.nbg.gov.ge

${ }^{3}$ Economic Policy Research Center. 2020. COVID-19 Economic Consequences for the World and Georgia. www.eprc.ge

${ }^{4}$ World Travel and Tourism Council. 2018. GLOBAL ECONOMIC IMPACT \& ISSUES 2018 www.wttc.org
} 
as other indirectly related economic activities. To stop the spread of the pandemic and to localize it, the government approved regulations according to which all business entities activities had been suspend for a certain period except for grocery stores and pharmacies. According to the International Monetary Fund, the Georgian economy will experience a recession in 2020 and will reach $-4 \%{ }^{5}$ A more pessimistic forecast is made by Galt \& Taggart in its report where company notes that the economic growth will be $-6 \%,{ }^{6}$ although research on this issue continues, which would be based on more in-depth analysis and modeling. The construction business received a significant blow, which reflected in a sharp decline in sales and falling real estate prices. This situation turned out to be very dramatic in the first stage of the pandemic, because some companies in the construction industry was unable to repay bank loans. Generally in this business segment whole debt amounted to be about 9.2 billion GEL (18\% of GDP). ${ }^{7}$

During the COVID-19 pandemic, the Georgian National Center for Disease Control and Public Health had consultation with international partners, mainly ambassadors from countries that already had some experience fighting against the virus. Through these meetings, there was analyzed received information and an action plan was further developed. The center established active communication with the public and various target groups, through which knowledge and recommendations from strategic partners share. ${ }^{8}$ The Shota Rustaveli National Science Foundation of Georgia is actively participating in the ISTC COVID-19 pandemic regional meeting, which has an interdisciplinary nature and envisages the establishment of a regional scientific council. Its basic aim is to reduce corona virus induced damage in various sectors through coordinated programs, conferences and workshops in the Caucasus and Central Asia to help governments Improve Collaboration. ${ }^{9}$

The difficult situation created by the pandemic, which has strongly affected Georgia, requires the use of transdisciplinary approaches, which will allow the country to get the maximum effect and reduce losses in the current situation. Dr. Roderick Lawrence points out in his study that overcoming the social problems caused by the corona virus requires the use of both scientific and non-scientific knowledge and know-how, which in a way forms the common knowledge base. This aspect is very important in this situation, because the problems caused by the pandemic are complex and require coordination of different disciplines, government policies, individual and public responsibility. ${ }^{10}$ Within the framework of the anti-crisis plan of the Government of Georgia, the country participated in the project "The Georgian Reality: Sustainable Scholarly Studies during the COVID-19 Pandemic" supported by the World Pandemic Prevention Organization, which aims to facilitate coordinated transdisciplinary research in the world scientific community. ${ }^{11}$ The Ministry of Education noted that the data and findings obtained will be valuable not only in the current crisis but also will have significant importance for the future challenges. ${ }^{12}$ Georgia is involved in several transdisciplinary research projects, such as CaucaSusT - Transdisciplinarity for Sustainable Tourism Development in the Caucasus Region ${ }^{13}$ and The Caucasus Network for Sustainable Development of Mountain Regions. ${ }^{14}$ The aim of the projects is to study the problems in the field of tourism with the involvement of local people and other stakeholders, so that the results can be answered real-life problems of sustainable development. During the current pandemic, the tourism business received the hardest blow. Doctor of Geography, Professor Ioseb KhelaSvili in his study "Problem identification in

\footnotetext{
${ }^{5}$ International Monetary Fund. April 2020. World Economic Outlook: The Great Lockdown www.imf.org

${ }^{6}$ Galt \& Taggart. 2020. Covid 19 [Covid-19 Impact on the Georgian economy] www.galtandtaggart.com

${ }^{7}$ Government of Georgia. 2020. "Report on the measures taken by the Government of Georgia against Covid-19“ www.gov.ge

${ }^{8}$ National center for disease control and public health. 2020. COVID-19 in Georgia report 3rd revision www.ncdc.ge

${ }^{9}$ Shota rustaveli national science foundation of Georgia. 13.12.2020. ISTC regional meeting on elimination of Covid Infection www.rustaveli.org.ge

${ }^{10}$ Dr. Roderick Lawrence. 24.09.2020. Advancing with Transdisciplinarity: Effective Responses for Coronavirus. Transdisciplinary Journal of Engineering \& Science www.atlas-tjes.org

${ }^{11}$ See source 10

${ }^{12}$ First channel. 15.05.2020. Mikheil Chkhenkeli Minister of Education and Science: The importance of fundamental and research science in fighting the pandemic has become clear to everyone www.1tv.ge

${ }^{13}$ CaucaSusT. 2020. Developing and Implementing a Transdisciplinary Field Case Study Course: Manual for University Lecturers www.caucasust.boku.ac.at

${ }^{14}$ Scientific Network for the Caucasus Mountain Region. 2020. Sustainable Caucasus Newsletter www.sd-caucasus.com
} 
tourism through transdisciplinary research (Georgia as a case)" notes that, "at the current stage, there is a tendency to separate theoretical and practical knowledge. This led to the so-called the emergence of transdisciplinary approaches focused on overcoming these problems." ${ }^{15}$ The need for this approach is discussed by Dr. Merab Khokhobaia in his paper where he notes that the tourism sector is complex and includes various stakeholders, sectors. Thus, in order to put scientific knowledge into practice, it is necessary to use a transdisciplinary approach, which will facilitate the integration process and fill the space between them. ${ }^{16}$

Taking into consideration the above-mentioned aspects, we can say that the severest crisis has affected to the tourism, construction and shopping entertainment centers. Companies began reducing staff in order to minimize costs and thus avoid bankruptcy. Rising unemployment remains a major challenge for the country, despite the government's efforts to help business by taking various measures. The problem is global and economic incentives implemented locally cannot be a panacea under these conditions, so the importance of the use transdisciplinary research in this situation is more tremendous.

Funding: This short letter received no external funding.

Conflicts of Interest: The authors declares no conflict of interest.

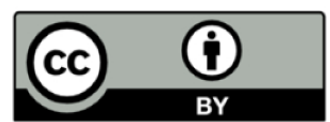

Copyright (C) 2021 by the authors. This is an open access article distributed under the Creative Commons Attribution License (https://creativecommons.org/licenses/by/4.0/), which permits unrestricted use, distribution, and reproduction in any medium, provided the original work is properly cited.

\section{About the Authors}

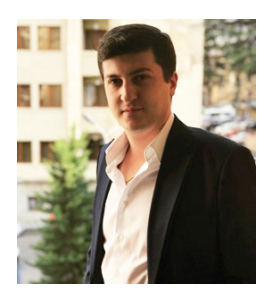

Zurabi Jankhoteli graduated from the Faculty Business Administration in Finances at the International Black Sea University (Tbilisi, Georgia) with Honours. He has a Master Degree from the Grigol Robakidze University (Tbilisi, Georgia), thesis was about "The Impact of Viral Advertising on Company Marketing". He is PHD student at East European University Faculty of Business and Engineering (Tbilisi, Georgia).

He participated in annual conference "Creative Thinking For Business - 2015" and also successfully complete "Writing Project" certificate programme at International Black Sea University. He is a member of Accreditation Group for Self-Assessment of the Doctoral Program in Educational Science in East European University. In 2017 he founded online shopping company "Classic Room" which introduces jewelry products from different countries (www.classicroom.ge).

\footnotetext{
${ }^{15}$ Ioseb Khelashvili. 2017. Problem identification in tourism through transdisciplinary research (Georgia as a case). Ivane Javakhishvili Tbilisi State University Press, Tbilisi, pp. 628-634. ISBN 978-9941-13-650-4 www.eprints.tsu.ge

${ }^{16}$ Merab Khokhobaia. 2018. Transdisciplinary Research Methodology for the Tourist destination Development. Ivane Javakhishvili Tbilisi State University Press, Tbilisi, pp. 517-521. ISBN 978-9941-13-764-8 www.eprints.tsu.ge
} 


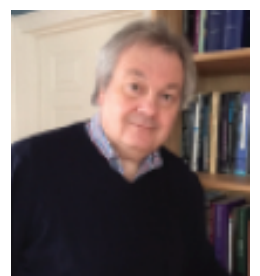

Dr. Paul Gibbs is Professor and Director of the Doctoral School, East European University. He is professor emeritus at Middlesex University, founder of the Centre for Education Research and Scholarship, and visiting professor at UTS Sydney and Azerbaijan university. His is a fellow of ATLAS as well as the Centre for Higher Education Policy, New College Oxford. He is an educator and researcher having taught notions of transdisciplinarity alongside social realism and Heideggerian hermeneutics. He has over 30 successful transdisciplinary professional doctorate students. He has published 20 books on topics ranging from the marketing of higher education to vocationalism and higher education and has published more than 100 academic articles. His particular approach to transdisciplinarity is informed by the works of Heidegger, Duns Scotus, and Deleuze and the theoretical insights of Basarab Nicolescu. He is also the series editor of SpringerBriefs on Key Thinkers in Education. 